\title{
An application of multiobjective programming to the study of workers' satisfaction in the Spanish labour market
}

OSCAR D. MARCENARO- GUTIÉRREZ

MARIANO LUQUE GALLEGO

FRANCISCO RUIZ DE LA RÚA 
El Centro de Estudios Andaluces es una entidad de carácter científico y cultural, sin ánimo de lucro, adscrita a la Consejería de la Presidencia de la Junta de Andalucía.

El objetivo esencial de esta institución es fomentar cuantitativa y cualitativamente una línea de estudios e investigaciones científicas que contribuyan a un más preciso y detallado conocimiento de Andalucía, y difundir sus resultados a través de varias líneas estratégicas.

El Centro de Estudios Andaluces desea generar un marco estable de relaciones con la comunidad científica e intelectual y con movimientos culturales en Andalucía desde el que crear verdaderos canales de comunicación para dar cobertura a las inquietudes intelectuales y culturales.

Las opiniones publicadas por los autores en esta colección son de su exclusiva responsabilidad

(C) 2007. Fundación Centro de Estudios Andaluces

Depósito Legal: SE- 4093-07

Ejemplar gratuito. Prohibida su venta. 


\title{
AN APPLICATION OF MULTIOBJECTIVE PROGRAMMING TO THE STUDY OF WORKERS' SATISFACTION IN THE SPANISH LABOUR MARKET.
}

\author{
Oscar D. Marcenaro-Gutiérrez ${ }^{\dagger, \ddagger}$ \\ Departamento de Economía Aplicada (Estadística y Econometría) \\ Universidad de Málaga \\ Mariano Luque Gallego \\ Departamento de Economía Aplicada (Estadística y Econometría) \\ Universidad de Málaga \\ Francisco Ruiz de la Rúa* \\ Departamento de Economía Aplicada (Estadística y Econometría) \\ Universidad de Málaga
}

\footnotetext{
† Autor para correspondencia: odmarcenaro@uma.es.

\$ This author greatly acknowledges the financial support granted by the FUNDACIÓN CENTRO DE ESTUDIOS ANDALUCES under research contract ECOD2.07/016.

* F. Ruiz's research has also been supported by the Spanish Ministry of Education and Science (mobility program, PR2005-0212).
} 


\section{RESUMEN}

En este artículo se emplea la metodología multiobjetivo para estudiar los niveles de satisfacción de los trabajadores españoles. Los datos procedentes de una encuesta de panel llevada a cabo en algunos países europeos son utilizados para construir un modelo basado en análisis previos de tipo estadístico y econométrico. Los resultados de éstas técnicas nos permiten implementar estimaciones de punto de referencia para determinar el perfil de los trabajadores españoles más satisfechos. Partiendo de los resultados de esa técnica se flexibiliza el modelo mediante la metodología propia de la Programación por Metas; de esta forma analizamos cuales son las políticas que pueden ser acometidas para incrementar el nivel de satisfacción de los trabajadores.

Palabras clave: Satisfacción laboral, análisis econométrico, Programación Multiobjetivo.

\section{ABSTRACT}

In this paper, a multiobjective scheme is used to study the satisfaction levels of the Spanish workers. Data obtained from a panel survey conducted in several European countries are used to build up a multiobjective model, on the basis of a previous statistical and econometric analysis of these data. Then, a Reference Point based method is implemented to determine the profile of the most satisfied worker in Spain nowadays. Finally, a combined Goal Programming - Reference Point approach is used to determine policies than can be carried out in order to increase the workers' satisfaction levels.

Keywords: Workers' Satisfaction, Econometric analyses, Multiobjective Programming.

JEL Classification: J28. 


\section{Introduction.}

Since the European Union was created numerous economic and social policy reforms have been implemented as a way of reaching some kind of socio-economic convergence among the member states of the Union. Many of these economic changes have been focused on the national labour markets (reform of the unemployment protection system, working time, minimum wage, etc...), to make them more flexible, as the prevalent rigidities in these markets were thought to be the origin of the high unemployment rates observed across Europe in the last two decades. Regardless of the questionable success of many of these measures, what seems clear is the general lack of concern on job quality/satisfaction despite its potential link with (higher) worker's productivity, via (lower) absenteeism, (lower) turnover, (lower) tardiness and, broadly speaking, (higher) job performance and firm return.

Ahead of this, job satisfaction is important in its own right as a part of social welfare. Moreover, measures of job satisfaction, as proxy for job quality, seem to be useful predictors of future labour market behaviour. Workers' decisions about whether to work or not, what kind of job to accept or stay in, and how hard to work are all likely to depend in part upon worker's subjective evaluation of their work, in other words on their job satisfaction. Most of the previous studies on job satisfaction have been focused on the effect of earnings on different measures of job satisfaction (see, e.g., Clark (2005) and Gamero (2005)). Recently, some evidence has come out that demonstrates the existence of some factors of job quality that affect job satisfaction but are not correlated with earnings (e.g. Leontaridi \& Sloane (2001)), contrasting with the traditional belief of economists who thought on earnings as the main approach to compute the value of jobs. In fact, job satisfaction acts as a summary measure of the different aspects of job quality, a number of which are difficult to observe or measure. As such, the use of the satisfaction information may help to explain workers' behaviour better than data on, for example, pay and hours. For instance, Freeman (1978) using American panel data shows that job satisfaction is a strongly significant predictor of quits, even more in some cases than wages.

We restrict our attention to job satisfaction as a subjective measure of worker's wellbeing because, although it is not necessarily the ideal instrument for capturing well-being, it is the best proxy available in the dataset. But, based on the previous comments, it seems clear that job satisfaction is not a single dimensional measure. Rather than that, there can be different (and conflicting) aspects of job satisfaction. Consequently, we concentrate on 
different aspects of job satisfaction as proxy for job quality in an attempt to quantify worker's individual preferences. More precisely we are trying to answer the following questions: What kind of workers are attaining better satisfaction levels than the rest? On the other hand, may this information be used to determine policies in order to increase workers' satisfaction? In other words, may governments affect workers' satisfaction/job quality?

In order to answer these questions, the multidimensional aspect of the problem has to be taken into account. As previously commented, job satisfaction is a wide concept that comprises several conflicting aspects. Therefore, it does not seem appropriate to simply "maximize" job satisfaction. This is why, in our opinion, the use of the Multiobjective Programming approach is more suitable than classical single objective schemes. To our knowledge, such multicriteria analysis has not been applied to the job satisfaction issue so far.

The application of multicriteria techniques to an econometric model allows us to obtain information and results that the classical econometric techniques are not able to provide, like for example to identify 'optimal workers'. Furthermore, the post-optimization analysis can determine the impact of the change of the independent variables on the different satisfaction levels.

Nevertheless, we will not depart from the econometric analysis, as it can provide very useful modelling tools. In fact, the linear regression analysis is the basis for the determination of the objective functions and, moreover, another of the novel aspects of this paper lies in the use of such analysis and the confidence intervals to build flexible constraints for the problem.

Many are the multiobjective approaches that have been described in the literature (as commented in section 2). In our case, we want to establish certain satisfaction levels (namely, the good Danish levels) as reference or target values for the satisfaction objective functions. That is why the Reference Point approach is the most suitable technique for our case study. The use of this technique allows us to assure that the final solution will be weakly efficient (efficient in most of the cases), and the closest possible one to the reference levels. On the other hand, the constraints obtained from the econometric analysis correspond to dependencies observed in the data. But it is not accurate to assume that these dependencies will hold unaltered in the future. This is why a flexible framework that allows the (penalized) violation of certain constraints can give a better image of the possible future situation if certain decisions are made. Goal Programming is probably the most suitable multiobjective 
technique to deal with such soft constraints. For this reason the methodological framework used in this paper is a combined Reference point - Goal Programming scheme.

Summarizing, we propose to analyse this problem with a two-steps procedure. Firstly, we will proceed with econometric estimates to obtain a causal relationship between workers' satisfaction and an individual/contextual set of features. To address these issues we use comparable survey data across eight different European countries containing records on seven job-related characteristics which workers say they value: earnings, job security, type of work, number of working hours, working times, working conditions/environment and how far the job is. These are all argued to be key correlates of a good job or of job satisfaction. At a second stage we will make use of multiobjective programming techniques to disentangle the extent to which those correlations may be affected to achieve a satisfactory solution to the problem. Namely, a reference point approach will be used to describe the profile of the "most satisfied" Spanish workers in the present time, according to the data survey. Then, a combined reference point - goal programming scheme will be used to determine possible policies in order to increase workers' satisfaction levels.

The rest of the paper is organised as follows. In section 2 the basic concepts regarding multiobjective programming and, in particular, reference point and goal programming techniques are given. The model is built in section 3, using the econometric analysis of the data as the main basis. The problem is solved in section 4 , using two successive approaches, and results are commented on. Finally, some conclusions are drawn in section 5.

\section{Basic Concepts of Multiobjective Programming.}

In this section, the basic definitions and notations regarding multiobjective programming are provided. Let us consider the following general multiobjective problem:

$$
\begin{array}{lc}
\max f(\mathbf{x}) & f_{1}(\mathbf{x}), f_{2}(\mathbf{x}), \ldots \ldots, f_{k}(\mathbf{x}) \\
\text { s.t.: } & \mathbf{x} \quad X
\end{array}
$$

where $X \quad R^{n}$ is called the feasible region (constrained set of feasible solutions), and $Z \quad f(X)$ is regarded as the criterion space. Let us assume that all functions $f_{i}(\mathbf{x})$ are continuously differentiable, and that $X$ is a nonempty and compact set.

A decision vector $\mathbf{x}^{*} \quad X$ is said to be efficient or Pareto optimal for problem (1) if there does not exist any other vector $\mathbf{x} \quad X$ such that $f_{i}\left(\mathbf{x}^{*}\right) \beta f_{i}(\mathbf{x}) \quad i \quad 1, \ldots, k$ and 
$f_{j}\left(\mathbf{x}^{*}\right) \quad f_{j}(\mathbf{x})$ for al least one index $j$. The corresponding objective vector $\mathbf{z}^{*} f\left(\mathbf{x}^{*}\right)$ is called a non-dominated criterion vector. A decision vector $\mathbf{x}^{*} X$ is said to be weakly efficient or weakly Pareto optimal for problem (1) if there does not exist any other $\mathbf{x} X$ such that $f_{i}\left(\mathbf{x}^{*}\right) \quad f_{i}(\mathbf{x}) \quad i \quad 1, \ldots, k$. The efficient set of problem (1) will be denoted by $\mathrm{E}$ and $Z \quad f(E)$ is the set of non-dominated criterion vectors.

The ideal and nadir vectors are formed, respectively, by the best and worst value that each objective can take in the efficient set:

$$
\begin{aligned}
& z_{i}^{*} \max _{\mathbf{x} E} f_{i}(\mathbf{x}) \quad i \quad 1,2, \ldots, k \\
& \mathbf{z}^{*} \quad z_{1}^{*}, \ldots, z_{k}^{* T} \\
& m_{i}^{*} \min _{\mathbf{x} E} f_{i}(\mathbf{x}) \quad i \quad 1,2, \ldots, k \\
& \mathbf{m}^{*} \quad m_{1}^{*}, \ldots, m_{k}^{* T}
\end{aligned}
$$

Given that the ideal solution for each function $f_{i}$ is always a weakly efficient solution of the multiobjective problem, it follows straightforwardly that the ideal values can be obtained by means of maximizing each objective function separately over the feasible set. On the other hand, nadir values are usually difficult to obtain, because a minimization has to be carried out over the efficient set, which is not known beforehand (see Miettinen (1999) for further details about the nadir point).

Estimates of these values are antiideals values, obtained from a payoff matrix:

$$
\begin{aligned}
& f_{1} f_{2} \quad f_{k} \quad z_{i}^{*} \max _{\mathbf{x} x} f_{i}(\mathbf{x}) \quad i \quad 1,2, \ldots, k \quad \text { (ideals) } \\
& \begin{array}{l}
\mathbf{x}_{1}^{*} \mu \\
\mathbf{x}_{2}^{*} \mu
\end{array}\left(\begin{array}{cccc}
z_{1}^{*} & z_{12} & \cdots & z_{1 k} \\
z_{21} & z_{2}^{*} & \cdots & z_{2 k}
\end{array}\right) \quad \bar{z}_{i} \min _{j\{1, \ldots k} z_{j i} \quad i \quad 1,2, \ldots, k \quad \text { (antiideals) } \\
& \left.\begin{array}{c}
\cdots \\
\mathbf{x}_{k}^{*} \mu
\end{array} \quad \begin{array}{cccc}
\cdots & \cdots & \cdots & \cdots \\
z_{k 1} & z_{k 2} & \cdots & z_{k}^{*}
\end{array}\right) \quad \overline{\mathbf{z}} \quad \bar{z}_{1}, \ldots, \bar{z}_{k}{ }^{T} \text { is an estimation of nadir point } \mathbf{m}^{*}
\end{aligned}
$$

While it is true (see Miettinen (1999)) that the antiideal is not always a good estimate of the nadir value, the largest errors usually take place in highly non-convex environments. Nevertheless, the antiideals are used very frequently in normalizing schemes. In this study, where our problem is a linear mixed integer model, this approximation has worked reasonably well, and no bias effect has been observed in the solutions obtained.

Multiobjective methods are traditionally classified into three groups, depending on how the decision maker (DM) provides his preferential information (see Steuer (1986) for further details). If no information is available beforehand, then we use a method without $a$ 
priori information, whose aim is to generate a number of efficient solutions, in order to obtain an approximation of the efficient set (or, in the best case, to obtain the whole efficient set). The DM must choose a solution afterwards. The weighting method and the E-constraint methods are examples of this class of algorithms. If the DM gives his preferences before solving the problem, then we use a method with a priori information, in order to search for the solution that is, in some sense, closest to the DM's wishes. Goal Programming and Reference Point algorithms are methods with a priori information. Finally, if the information is gradually given by the DM along the resolution process, and solutions are iteratively generated according to the preferences, we use interactive methods. There are plenty of interactive methods in the literature, which are usually classified attending to the kind of information requested to the DM at each step of the algorithm. In Steuer (1986), a full survey of interactive methods can be found, while in Luque et al (2007), some relations between the different kinds of information are derived.

In this paper, methods with a priori information are used, and more precisely, a combination of the Reference Point approach and Goal Programming has been chosen. Let us briefly describe both schemes. In the former case a reference point, denoted by q $q_{1}, \ldots, q_{k}{ }^{T}$, is specified by the DM, expressing desirable values for each objective. Given these values, and a vector of weights $\mathrm{M} \quad \mathrm{M}, \ldots, \mathrm{M}_{*}{ }^{T}$, the so-called achievement scalarizing function is built (see Wierzbicki (1986)):

$$
s(\mathbf{q}, f(\mathbf{x}), \boldsymbol{\mu}) \quad \max _{i 1, \ldots, k}\left[\mathrm{~N}_{i} q_{i} \quad f_{i}(\mathbf{x})\right]
$$

which is minimized over the feasible set:

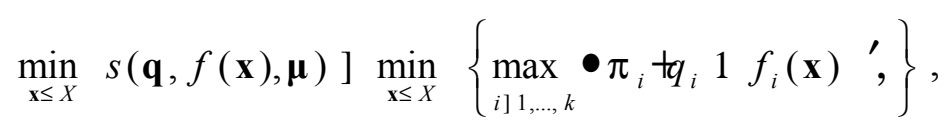

This is equivalent to solve the following differentiable problem:

$$
\begin{aligned}
& \min _{\mathbf{x}, \mathrm{A}} \mathrm{A}
\end{aligned}
$$

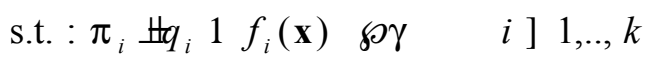

$$
\begin{aligned}
& \text { x } X
\end{aligned}
$$

The weights $\mathrm{M} \mathbf{M}, \ldots, \mathrm{M}^{T}$ are generally instrumental, for example, normalizing weights. A widely used normalization is: 


$$
\mathrm{M} \frac{1}{z_{i}^{*} \bar{z}_{i}} \quad i \quad 1, . ., k
$$

As proved in Wierzbicki (1986), the use of this achievement scalarizing function assures to obtain a weakly efficient solution. Moreover, Wierzbicki (1986) also proves that if the optimal solution of the minmax problem is unique, then it is Pareto efficient. Although there are other functions that guarantee efficiency (see, for example, Miettinen (1999)), we have decided to keep this one for simplicity. The resulting single objective optimisation problem will be solved using the NAG library (Numerical Algorithms Group) for C language (see Nag $\mathrm{C}$ (2000)). The implementation has been carried out in $\mathrm{C}++$ language by using the Microsoft Visual $\mathrm{C}++$ compiler and adapting the software PROMOIN (C) (for further details, see Caballero et al (2002)).

On the other hand, the Goal Programming approach lets us model the so-called soft constraints, which are constraints whose violation is allowed ${ }^{1}$ although penalized some way. Namely, given a set of hard constraints:

$$
g_{j}(\mathbf{x}) \beta 0, \quad j=1, \ldots, s
$$

the following goals can be built:

$$
g_{j}(\mathbf{x})+n_{j}-p_{j}=0, \quad j=1, \ldots, s
$$

The corresponding non desired deviation variables (in our case, the positive deviation variables $p_{j}$ ) are minimized. In this case, Caballero et al. (Caballero et al (1996)) show that the negative deviation variable can be dropped, and the goal takes the form:

$$
g_{j}(\mathbf{x})-p_{j} \beta 0, \quad j=1, \ldots, s
$$

If the minmax approach is used, the Goal Programming problem is stated as follows:

$$
\begin{array}{llllll}
\min _{\mathbf{x}, \mathrm{B}} & \mathrm{B} & & & \\
\text { s.t. : } & p_{j} \beta \mathrm{B} & j & 1, . ., s & \\
& g_{j}(\mathbf{x}) & p_{j} \beta & 0 & j & 1, . ., s \\
& \mathbf{x} & X & & & \\
& p_{j} \rho 0 & j & 1, . ., s &
\end{array}
$$

\footnotetext{
${ }^{1}$ This will allow us to provide flexibility to certain constraints of our model, e.g. one establishing bounds on the weekly salary.
} 
As it will be explained in the next section, the reference point approach is used for the objectives regarding the workers' satisfaction, taking as reference values the Danish satisfaction levels, while the Goal Programming scheme is used to allow some flexibility in a number of constraints of the original model.

Finally, let us to point out that the model which will be built in the next section is a mixed integer problem. Namely, some of the variables are binary. Such problems have already been treated in the scientific literature. For example, Alves \& Climaco (2004) presented a decision support system to solve multiobjective integer and mixed-integer programming problems using interactive reference point approaches.

\section{Construction of the Model.}

The multiobjective model of this problem has been built following a series of steps. First, a series of data regarding the Spanish workers' satisfaction levels, as well as some of their personal characteristics, have been collected from an European survey. Then, an econometric analysis is carried out in order to find dependence relations of the satisfaction levels with respect to these data, as well as possible correlations among some data themselves. Some conclusions are obtained from this econometric analysis. Based on these results, we identify the significant decision variables of the problem, and the objective functions and constraints are built. Finally, a combined Reference Point - Goal Programming scheme is used to solve the resulting multiobjective problem. Let us now describe in further detail each of these steps.

\subsection{Data.}

The information analysed in this paper comes largely from the European Community Household Panel (ECHP, see Peracchi (2002)) for the period 1995-2001, in which workers provide information on a wide range of personal characteristics and job attributes ${ }^{2}$. This survey was conducted, under Eurostat supervision, across 15 European Community state members during the period 1994-2001. We have selected the data corresponding to Spain for our study, together with the satisfaction levels of Denmark (the highest ones in the study) as reference levels. We restrict the sample to those workers, working in the private sector, whose

\footnotetext{
${ }^{2}$ The first wave of this panel survey (1994) is not considered in the analyses due to the lack of information on some of the relevant variables for the analyses.
} 
minimum age is 26 . The reason for choosing this threshold age is that around this age is the time at which people start looking for a job ${ }^{3}$.

Workers in the ECHP were asked to evaluate seven different aspects of a job, on a scale from 1 to 6 , where 1 is "not satisfied at all" and 6 is "fully satisfied". The job aspects presented were: earnings, job security, type of work, number of working hours, working times, working conditions/environment and distance to job. The precise wording of the questions was: How satisfied are you with your present job in terms of ...? These categories are not exhaustive, but they serve to summarise many of the job characteristics that workers find important.

The simple average provides a satisfaction index (the bigger the average, the most satisfied), which is comparable across the populations if we assume the linearity across responses. On the whole, there is a high degree of concordance across these mean values within each country ${ }^{4}$; consequently we can establish somehow a ranking of countries in terms of satisfaction regardless of the particular satisfaction aspect evaluated. In this sense we found that Denmark keeps the highest job satisfaction (in most aspects, i.e., earnings, job security, employment type, working hours and working times) all over the period, and a higher average satisfaction (4.78). On the contrary Mediterranean countries such as Spain, Greece and Italy show the lowest satisfaction levels. Figure 1 illustrates that, with the exception of France, earnings is ranked as the lowest-rated out of the seven characteristics considered. The highest-ranked aspects (across all countries) are type of work, distance to job and working times.

On the other hand, the different values of the satisfaction levels for each country confirm that there is some degree of conflict between the criteria, in the sense that policies designed to improve a specific satisfaction level would probably make other(s) get worse. For this reason, the multicriteria methodology is especially suitable for this model.

With regard to the decision variables of our model, they have been listed in Table 1 (Appendix). We ended up with 29 variables, most of which are under individual decision makers control. As shown in Table 1, there are 4 continuous variables and the rest are binary.

\footnotetext{
${ }^{3}$ More precisely $90 \%$ of the workers surveyed report 26 as the age when the highest level of education was completed.

${ }^{4} \mathrm{We}$ had to restrict the sample to just eight countries (Belgium, Denmark, France, Greece, Ireland, Italy, Portugal and Spain) due to the lack of information for the rest of countries in some waves on the relevant questions for our analyses.
} 
For all the binary variables, a reference group has been considered which is assumed to equal 1 if the rest of the variables are 0 . For example, for the education level group, if edhigher $=$ $e d s e c=0$, then the individual belongs to the reference group (first level of secondary education or lower). This fact has been taken into account in the regression analysis carried out. Besides these 29 variables, 6 instrumental year dummies have been used, in order to take into account effects due to the precise year when each survey was conducted. Summary statistics, distinguishing by gender, for the whole set of variables incorporated in the analysis are shown in Table 2.

The figures stated in Table 2 disclose some well established differences between male and female workers. The proportion of female workers is much lower than male. Spain like some other Southern European countries (Greece and Italy), but Portugal, still shows a much lower female participation rate than the Nordic countries and therefore patterns of women and men in the labour market are highly probable to differ. Consequently, we will run separate estimates for men and women. Nonetheless, there is notable consistency between men and women with respect to satisfaction with different working aspects. Only in the case of working conditions and distance to work women state higher satisfaction levels than men (no

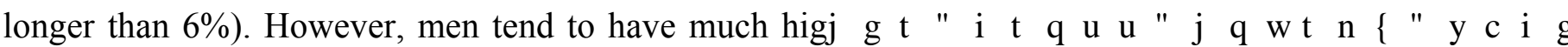
equivalent to $18.8 \%$ ) than their female counterparts, despite having considerably lower education levels. This pattern fits with differences in the labour force participation rates and suggests a stronger relationship between education and labour market participation in countries with a low overall female participation rate (Spain, Italy and Greece).

We also control in our estimates for net family income (discounting worker's own income). This variable is trimmed by treating income observations below 1st and above 99th percentile of income as missing data, to avoid the blurring effects of extreme values. Interestingly female employees enjoy higher net family income, reinforcing the previous argument that men are those who get higher earnings.

Regarding working hours, slightly more than 1 in 5 report being currently working more than forty hours a week; however the figure raises up to $37 \%$ for men. Likewise supervisory or intermediate statuses are more likely among men. Being married or having young children is definitively a drawback for women to participate in the labour market as reflected by the figures in Table 2, where it can be seen that the proportion of married women and/or women having young children is substantially lower than men. 
Table 2. Descriptive Statistics by gender (Spanish workers).

\begin{tabular}{|c|c|c|c|c|c|c|}
\hline \multirow[b]{2}{*}{ Variable } & \multicolumn{2}{|c|}{ Both } & \multicolumn{2}{|c|}{ Male } & \multicolumn{2}{|c|}{ Female } \\
\hline & Mean & Std. Dev. & Mean & Std. Dev. & Mean & Std. Dev. \\
\hline \multicolumn{7}{|l|}{ Satisfaction in terms of: } \\
\hline Earnings & 3.23 & 1.30 & 3.24 & 1.28 & 3.21 & 1.33 \\
\hline Job security & 3.92 & 1.49 & 3.92 & 1.47 & 3.94 & 1.54 \\
\hline Type of works & 4.19 & 1.29 & 4.22 & 1.25 & 4.13 & 1.35 \\
\hline Number of working hours & 3.72 & 1.38 & 3.68 & 1.36 & 3.80 & 1.40 \\
\hline Working times & 4.03 & 1.36 & 4.03 & 1.32 & 4.04 & 1.42 \\
\hline Working conditions & 4.14 & 1.32 & 4.04 & 1.33 & 4.33 & 1.29 \\
\hline Distance to job & 4.07 & 1.46 & 3.99 & 1.46 & 4.22 & 1.45 \\
\hline Gender $($ female $=1)$ & 0.36 & 0.48 & & & & \\
\hline Gross hourly wage & 6.67 & 3.49 & 7.08 & 3.56 & 5.96 & 3.24 \\
\hline \multicolumn{7}{|l|}{ Education level: } \\
\hline Higher education & 0.26 & 0.44 & 0.22 & 0.42 & 0.31 & 0.46 \\
\hline Secondary education & 0.23 & 0.42 & 0.21 & 0.41 & 0.25 & 0.44 \\
\hline Net Family Income $\left(10^{3} €\right)$ & 7.27 & 7.87 & 6.24 & 7.47 & 9.07 & 8.24 \\
\hline Age & 33.19 & 9.74 & 33.83 & 10.00 & 32.05 & 9.15 \\
\hline \multicolumn{7}{|l|}{ Job seniority: } \\
\hline Seniority 3-4 & 0.17 & 0.37 & 0.17 & 0.37 & 0.16 & 0.37 \\
\hline Seniority 5-9 & 0.20 & 0.40 & 0.20 & 0.40 & 0.20 & 0.40 \\
\hline Seniority $10-14$ & 0.11 & 0.32 & 0.12 & 0.33 & 0.10 & 0.31 \\
\hline Seniority $15+$ & 0.04 & 0.20 & 0.05 & 0.21 & 0.03 & 0.17 \\
\hline Working + 40 hours/week & 0.32 & 0.46 & 0.37 & 0.48 & 0.22 & 0.41 \\
\hline Permanent contract & 0.53 & 0.50 & 0.54 & 0.50 & 0.51 & 0.50 \\
\hline \multicolumn{7}{|l|}{ Occupational status: } \\
\hline Supervisory & 0.07 & 0.25 & 0.08 & 0.27 & 0.05 & 0.21 \\
\hline Intermediate & 0.14 & 0.35 & 0.16 & 0.37 & 0.12 & 0.32 \\
\hline Married & 0.54 & 0.50 & 0.58 & 0.49 & 0.47 & 0.50 \\
\hline Children $<6$ & 0.17 & 0.38 & 0.20 & 0.40 & 0.13 & 0.33 \\
\hline Unemployment duration & 65.85 & 69.04 & 61.04 & 59.51 & 74.34 & 82.55 \\
\hline \multicolumn{7}{|l|}{ Worker's Health: } \\
\hline Good health & 0.87 & 0.34 & 0.87 & 0.34 & 0.86 & 0.34 \\
\hline Fair health & 0.11 & 0.32 & 0.11 & 0.32 & 0.11 & 0.32 \\
\hline Regional unemployment rate & 17.95 & 10.75 & 13.94 & 8.35 & 25.02 & 10.88 \\
\hline \multicolumn{7}{|l|}{ Industry in current job: } \\
\hline Mining and quarrying & 0.01 & 0.12 & 0.02 & 0.14 & 0.00 & 0.05 \\
\hline Utilities and construction & 0.16 & 0.37 & 0.24 & 0.43 & 0.02 & 0.14 \\
\hline Sales hotel & 0.26 & 0.44 & 0.22 & 0.42 & 0.34 & 0.47 \\
\hline Transport & 0.06 & 0.23 & 0.07 & 0.26 & 0.03 & 0.17 \\
\hline Finance property & 0.11 & 0.32 & 0.09 & 0.28 & 0.16 & 0.37 \\
\hline Other industry & 0.07 & 0.26 & 0.04 & 0.19 & 0.13 & 0.34 \\
\hline \multicolumn{7}{|l|}{ Firm size: } \\
\hline Firm size 5-19 & 0.31 & 0.46 & 0.34 & 0.47 & 0.27 & 0.45 \\
\hline Firm size 20-99 & 0.27 & 0.44 & 0.28 & 0.45 & 0.24 & 0.43 \\
\hline Firm size 100-499 & 0.12 & 0.33 & 0.12 & 0.33 & 0.12 & 0.33 \\
\hline Firm size $500+$ & 0.07 & 0.26 & 0.08 & 0.26 & 0.07 & 0.25 \\
\hline \multicolumn{7}{|l|}{ Year dummies: } \\
\hline 1995 & 0.13 & 0.34 & 0.13 & 0.34 & 0.13 & 0.34 \\
\hline 1996 & 0.14 & 0.34 & 0.14 & 0.35 & 0.13 & 0.34 \\
\hline 1997 & 0.14 & 0.35 & 0.14 & 0.35 & 0.15 & 0.35 \\
\hline 1998 & 0.15 & 0.36 & 0.15 & 0.36 & 0.15 & 0.35 \\
\hline 1999 & 0.15 & 0.36 & 0.15 & 0.36 & 0.16 & 0.36 \\
\hline 2000 & 0.15 & 0.36 & 0.15 & 0.36 & 0.16 & 0.37 \\
\hline 2001 & 0.13 & 0.34 & 0.13 & 0.34 & 0.13 & 0.34 \\
\hline Observations & \multicolumn{2}{|c|}{16165} & \multicolumn{2}{|c|}{10318} & \multicolumn{2}{|c|}{$\mathbf{5 8 4 7}$} \\
\hline
\end{tabular}

Source: Author's own calculations from ECHP 1995-2001. 
Men report slightly lower unemployment spells (5 months on average), despite his lower formal qualification level, on average. Moreover, they are exposed to much lower regional unemployment rates. It deserves our attention the fact that the proportion of women working in the construction or transport sector is negligible as compared to men. This meaning that still persist some degree of segregation across occupations between male and female employees.

\subsection{Econometric Analysis.}

We start the econometric analyses by estimating simple linear regression models in which our job satisfaction measures are regressed on hourly wage in actual job and the set of explanatory variables above reported, pooling all six years. Satisfaction is a discrete ordered variable categorized into one of six response codes. Thus we first run ordered probit models, getting very close results to those showed by ordinary least squared estimations (OLS). For this reason, and in order to make more consistent the implementation of the Multiobjective Programming approach we decided to use the coefficients obtained from the linear regression model.

As previously outlined, we can proxy individual's well-being through different categories of "job satisfaction". The level for each of these satisfaction targets results from the combination of a set of individual and contextual features, unobservable factors and a random disturbance (E). The idea behind the OLS estimator is to minimize the latter term in order to get rid, as much as possible, of the so called "statistical noise". Indexing individuals by $i$ and the job satisfaction aspects analysed by $r$, this model can be represented by the following set of equations:

$$
\begin{aligned}
& \text { Satisfaction } j_{r} \quad \hat{\mathrm{A}}^{j} \quad \hat{\mathrm{B}}_{1}^{j} \text { ghwg }_{r} \quad \hat{\mathrm{B}}_{2}^{j} \text { edhigher } r_{r} \quad \ldots \quad \hat{\mathrm{B}}_{35}^{j} \text { year }_{r} \quad \mathrm{E}_{r}^{j} \\
& r=1, \ldots, N ; \quad j=1, \ldots, 7
\end{aligned}
$$

where Satisfaction $j_{r}$ is a measure of the satisfaction category $j$ of individual $r$, and $g h w g_{r}$, edhigher ${ }_{r}, \ldots, f_{s} 500_{r}$, a group of explanatory variables; $E_{r}$ is a random disturbance, $B$ a vector of slope coefficients and $\alpha$ a fixed but unknown population intercept. The size of the sample is represented by the value $N$. 
Therefore, we are assuming that each individual's job satisfaction is affected by random factors, which are inherently unobservable and distributed normally. This type of parsimonious model is characterized by the parametric nature of its specification.

Tables 3 and 4 show the estimated coefficients on the key variables of interest. It also reports the $t$ statistics and the significance levels for each coefficient. Results are presented for the Spanish workers considered in our sample. Since separate regressions for men and women are reported, we have computed tests for equal coefficients across estimates, in order to illustrate the significance for the observed differences between genders. The figures for these tests may be obtained from the authors upon request.

The estimated coefficients for the earnings variable show that all the constituent parts of job satisfaction are positively and significantly correlated with worker's hourly wage, regardless of the gender.

Surprisingly, job satisfaction appears to decrease with level of education. This is not a common result in the literature to date with a few exceptions; Clark and Oswald (1996) found greater satisfaction for the less educated in Britain in the early 1990s.

The effect of family income on job satisfaction varies quite substantially according to worker's gender. Men seem to be less demanding with earnings and job security as their family income increase, and, at the same time, are fussier with the type of work. On the other hand, women appear to be more dependent on family income to improve job satisfaction in any respect, except job security and distance to job. This would suggest some kind of differential psychological reference effect between sexes for the dependence on income.

Both, men and women, do better when they are young in terms of satisfaction, particularly when satisfaction with earnings and job security are under scrutiny.

The number of years continuously working for the same firm only keeps a straightforward correlation with satisfaction in terms of job security, which seems logical as the worker will have better prospects to stay in the firm as time goes. This is particularly relevant in Spain where the rate of temporary employment is one of the largest in Europe. 
Table 3. The Determinants of different aspects of job satisfaction (male workers).

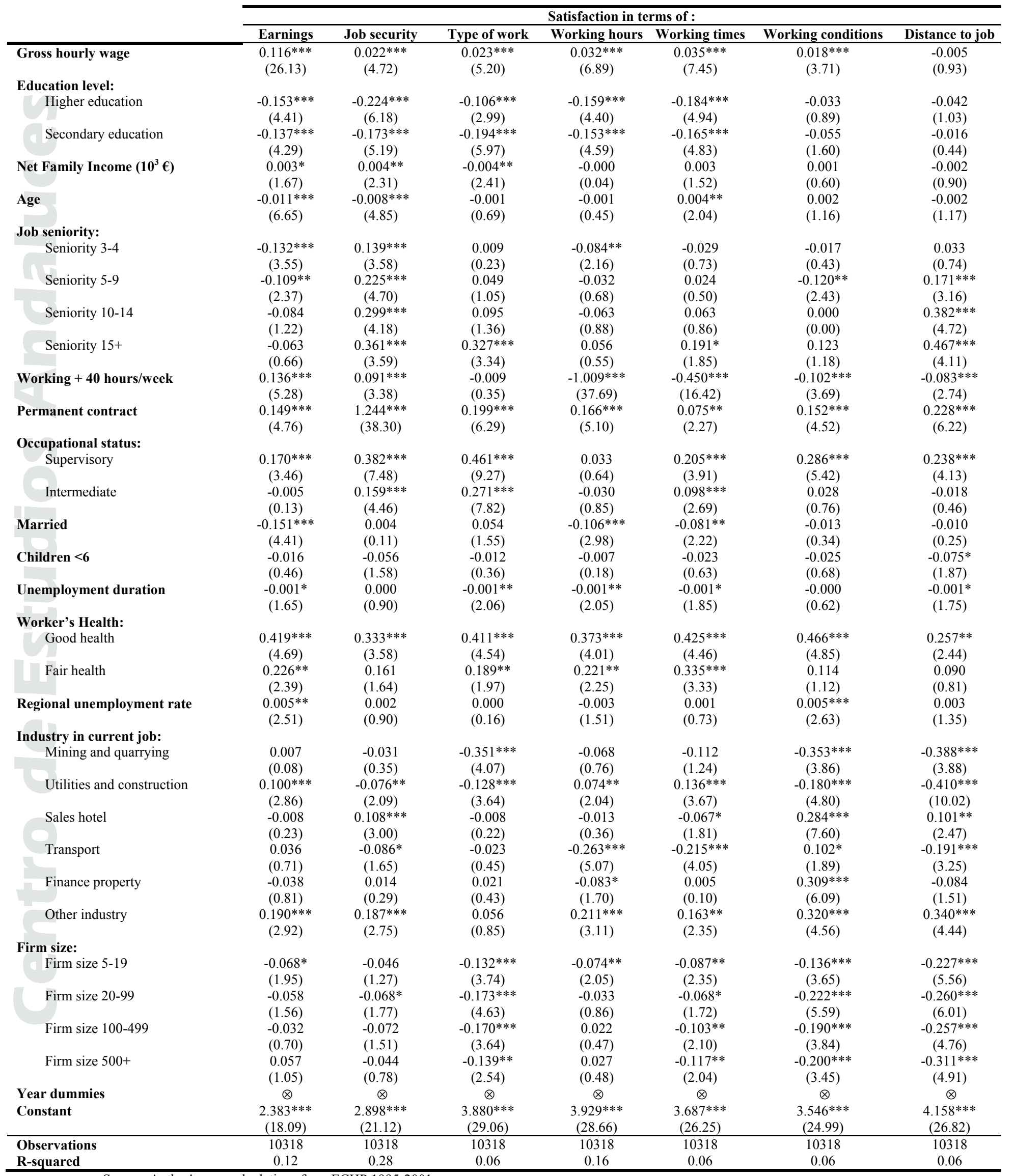

Source: Author's own calculations from ECHP 1995-2001.

Absolute value of $\mathrm{t}$ statistics in parentheses * significant at $10 \% ; * *$ significant at $5 \% ; * * *$ significant at $1 \%$. 
Table 4. The Determinants of different aspects of job satisfaction (female workers).

\begin{tabular}{|c|c|c|c|c|c|c|c|}
\hline & \multicolumn{7}{|c|}{ Satisfaction in terms of : } \\
\hline & Earnings & Job security & Type of work & Working hours & Working times & Working conditions & Distance to job \\
\hline Gross hourly wage & $\begin{array}{c}0.148 * * * \\
(22.45)\end{array}$ & $\begin{array}{c}0.042 * * * \\
(6.13)\end{array}$ & $\begin{array}{c}0.048 * * * \\
(7.02)\end{array}$ & $\begin{array}{c}0.050 * * * \\
(7.26)\end{array}$ & $\begin{array}{c}0.042 * * * \\
(5.76)\end{array}$ & $\begin{array}{c}0.019 * * * \\
(2.82)\end{array}$ & $\begin{array}{l}0.021 * * * \\
(2.84)\end{array}$ \\
\hline \multicolumn{8}{|l|}{ Education level: } \\
\hline Higher education & $\begin{array}{c}-0.259 * * * \\
(5.63)\end{array}$ & $\begin{array}{c}-0.196 * * * \\
(4.08)\end{array}$ & $\begin{array}{r}-0.050 \\
(1.04)\end{array}$ & $\begin{array}{c}-0.134 * * * \\
(2.76)\end{array}$ & $\begin{array}{c}-0.122 * * \\
(2.39)\end{array}$ & $\begin{array}{l}-0.071 \\
(1.53)\end{array}$ & $\begin{array}{l}-0.059 \\
(1.12)\end{array}$ \\
\hline Secondary education & $\begin{array}{c}-0.219 * * * \\
(5.07)\end{array}$ & $\begin{array}{c}-0.099 * * \\
(2.20)\end{array}$ & $\begin{array}{c}-0.091 * * \\
(2.03)\end{array}$ & $\begin{array}{c}-0.101^{* *} \\
(2.22)\end{array}$ & $\begin{array}{c}-0.163 * * * \\
(3.40)\end{array}$ & $\begin{array}{c}-0.104 * * \\
(2.38)\end{array}$ & $\begin{array}{l}-0.060 \\
(1.22)\end{array}$ \\
\hline Net Family Income $\left(10^{3} €\right)$ & $\begin{array}{c}0.005 * * \\
(2.42)\end{array}$ & $\begin{array}{l}0.002 \\
(0.97)\end{array}$ & $\begin{array}{c}0.004 * \\
(1.66)\end{array}$ & $\begin{array}{c}0.004 * \\
(1.93)\end{array}$ & $\begin{array}{c}0.008 * * * \\
(3.38)\end{array}$ & $\begin{array}{c}0.006 * * * \\
(2.87)\end{array}$ & $\begin{array}{l}0.002 \\
(0.97)\end{array}$ \\
\hline Age & $\begin{array}{c}-0.012 * * * \\
(4.78)\end{array}$ & $\begin{array}{c}-0.010^{* * *} \\
(3.61)\end{array}$ & $\begin{array}{c}-0.008^{* * *} \\
(2.90)\end{array}$ & $\begin{array}{r}-0.001 \\
(0.50)\end{array}$ & $\begin{array}{l}0.003 \\
(1.11)\end{array}$ & $\begin{array}{l}0.001 \\
(0.46)\end{array}$ & $\begin{array}{c}-0.008 * * * \\
(2.62)\end{array}$ \\
\hline \multicolumn{8}{|l|}{ Job seniority: } \\
\hline Seniority 3-4 & $\begin{array}{c}-0.135 * * * \\
\quad(2.70)\end{array}$ & $\begin{array}{c}0.174 * * * \\
(3.33)\end{array}$ & $\begin{array}{l}0.040 \\
(0.77)\end{array}$ & $\begin{array}{c}-0.087 * \\
(1.65)\end{array}$ & $\begin{array}{l}-0.004 \\
(0.07)\end{array}$ & $\begin{array}{c}-0.133 * * * \\
(2.62)\end{array}$ & $\begin{array}{l}0.059 \\
(1.02)\end{array}$ \\
\hline Seniority 5-9 & $\begin{array}{c}-0.242 * * * \\
(4.45)\end{array}$ & $\begin{array}{c}0.263 * * * \\
(4.64)\end{array}$ & $\begin{array}{l}0.084 \\
(1.49)\end{array}$ & $\begin{array}{c}-0.108^{*} \\
(1.90)\end{array}$ & $\begin{array}{l}-0.035 \\
(0.59)\end{array}$ & $\begin{array}{c}-0.155^{* * * *} \\
(2.82)\end{array}$ & $\begin{array}{l}-0.000 \\
(0.00)\end{array}$ \\
\hline Seniority $10-14$ & $\begin{array}{l}-0.109 \\
(1.54)\end{array}$ & $\begin{array}{c}0.286^{* * *} \\
(3.85)\end{array}$ & $\begin{array}{l}0.053 \\
(0.72)\end{array}$ & $\begin{array}{l}0.008 \\
(0.11)\end{array}$ & $\begin{array}{l}-0.034 \\
(0.43)\end{array}$ & $\begin{array}{r}-0.091 \\
(1.27)\end{array}$ & $\begin{array}{c}0.162 * * \\
(1.99)\end{array}$ \\
\hline Seniority $15+$ & $\begin{array}{r}-0.103 \\
(0.91)\end{array}$ & $\begin{array}{l}0.122 \\
(1.03)\end{array}$ & $\begin{array}{l}0.103 \\
(0.87)\end{array}$ & $\begin{array}{c}-0.048 \\
(0.41)\end{array}$ & $\begin{array}{l}0.023 \\
(0.19)\end{array}$ & $\begin{array}{c}-0.221 * \\
(1.93)\end{array}$ & $\begin{array}{c}0.225^{*} \\
(1.74)\end{array}$ \\
\hline Working + 40 hours/week & $\begin{array}{l}0.066 \\
(1.62)\end{array}$ & $\begin{array}{l}0.001 \\
(0.02)\end{array}$ & $\begin{array}{l}0.042 \\
(0.99)\end{array}$ & $\begin{array}{c}-1.046 * * * \\
(24.27)\end{array}$ & $\begin{array}{c}-0.517 * * * \\
(11.35)\end{array}$ & $\begin{array}{c}-0.160 * * * \\
(3.86)\end{array}$ & $\begin{array}{c}-0.100 * * \\
(2.14)\end{array}$ \\
\hline Permanent contract & $\begin{array}{c}0.139 * * * \\
(3.31)\end{array}$ & $\begin{array}{c}1.326^{* * *} * \\
(30.18)\end{array}$ & $\begin{array}{c}0.250 * * * \\
\quad(5.72)\end{array}$ & $\begin{array}{c}0.208 * * * \\
(4.69)\end{array}$ & $\begin{array}{l}0.076 \\
(1.62)\end{array}$ & $\begin{array}{c}0.098 * * \\
(2.30)\end{array}$ & $\begin{array}{c}0.103 * * \\
(2.15)\end{array}$ \\
\hline \multicolumn{8}{|l|}{ Occupational status: } \\
\hline Supervisory & $\begin{array}{c}0.207 * * \\
(2.51)\end{array}$ & $\begin{array}{l}0.322 * * * \\
(3.76)\end{array}$ & $\begin{array}{c}0.388 * * * \\
(4.55)\end{array}$ & $\begin{array}{c}-0.285^{* * * *} \\
(3.30)\end{array}$ & $\begin{array}{r}-0.062 \\
(0.68)\end{array}$ & $\begin{array}{l}0.101 \\
(1.22)\end{array}$ & $\begin{array}{l}0.050 \\
(0.54)\end{array}$ \\
\hline Intermediate & $\begin{array}{r}-0.071 \\
(1.33)\end{array}$ & $\begin{array}{l}0.210 * * * \\
(3.77)\end{array}$ & $\begin{array}{l}0.312 * * * \\
(5.62)\end{array}$ & $\begin{array}{r}-0.012 \\
(0.22)\end{array}$ & $\begin{array}{l}0.038 \\
(0.64)\end{array}$ & $\begin{array}{c}0.122 * * \\
(2.26)\end{array}$ & $\begin{array}{l}0.021 \\
(0.34)\end{array}$ \\
\hline Married & $\begin{array}{c}0.076^{* *} \\
(1.97)\end{array}$ & $\begin{array}{l}0.044 \\
(1.09)\end{array}$ & $\begin{array}{l}0.057 \\
(1.45)\end{array}$ & $\begin{array}{c}-0.019 \\
(0.48)\end{array}$ & $\begin{array}{c}-0.085^{* *} \\
(1.99)\end{array}$ & $\begin{array}{r}-0.042 \\
(1.09)\end{array}$ & $\begin{array}{l}0.006 \\
(0.15)\end{array}$ \\
\hline Children $<6$ & $\begin{array}{c}-0.104^{* *} \\
(1.96)\end{array}$ & $\begin{array}{r}-0.065 \\
(1.18)\end{array}$ & $\begin{array}{l}-0.036 \\
(0.66)\end{array}$ & $\begin{array}{l}0.077 \\
(1.37)\end{array}$ & $\begin{array}{l}0.064 \\
(1.08)\end{array}$ & $\begin{array}{l}0.012 \\
(0.22)\end{array}$ & $\begin{array}{l}-0.088 \\
(1.45)\end{array}$ \\
\hline Unemployment duration & $\begin{array}{l}0.000 \\
(1.43)\end{array}$ & $\begin{array}{c}0.001^{* * *} * \\
(3.34)\end{array}$ & $\begin{array}{l}-0.000 \\
(0.01)\end{array}$ & $\begin{array}{l}0.000 \\
(0.21)\end{array}$ & $\begin{array}{l}0.000 \\
(0.41)\end{array}$ & $\begin{array}{c}0.001^{* *} \\
(2.23)\end{array}$ & $\begin{array}{l}0.001 \\
(1.64)\end{array}$ \\
\hline \multicolumn{8}{|l|}{ Worker's Health: } \\
\hline Good health & $\begin{array}{c}0.308 * * * \\
(2.62)\end{array}$ & $\begin{array}{c}0.224 * \\
(1.82)\end{array}$ & $\begin{array}{c}0.349 * * * \\
(2.87)\end{array}$ & $\begin{array}{l}0.172 \\
(1.39)\end{array}$ & $\begin{array}{c}0.425 * * * \\
(3.26)\end{array}$ & $\begin{array}{c}0.529 * * * \\
(4.46)\end{array}$ & $\begin{array}{c}0.440 * * * \\
(3.28)\end{array}$ \\
\hline Fair health & $\begin{array}{l}0.152 \\
(1.22)\end{array}$ & $\begin{array}{l}0.074 \\
(0.57)\end{array}$ & $\begin{array}{l}0.100 \\
(0.78)\end{array}$ & $\begin{array}{l}0.054 \\
(0.41)\end{array}$ & $\begin{array}{c}0.249^{*} \\
(1.80)\end{array}$ & $\begin{array}{c}0.217^{*} \\
(1.73)\end{array}$ & $\begin{array}{l}0.140 \\
(0.98)\end{array}$ \\
\hline Regional unemployment rate & $\begin{array}{c}0.006^{* * *} \\
(3.08)\end{array}$ & $\begin{array}{c}0.004^{*} \\
(1.77)\end{array}$ & $\begin{array}{l}0.003 \\
(1.61)\end{array}$ & $\begin{array}{l}0.002 \\
(1.06)\end{array}$ & $\begin{array}{c}0.006^{* * *} \\
(2.83)\end{array}$ & $\begin{array}{c}0.006^{* * *} \\
(2.81)\end{array}$ & $\begin{array}{l}-0.001 \\
(0.24)\end{array}$ \\
\hline Industry in current job: & & & & & & & \\
\hline Mining and quarrying & $\begin{array}{l}0.344 \\
(1.09)\end{array}$ & $\begin{array}{l}0.454 \\
(1.38)\end{array}$ & $\begin{array}{r}-0.328 \\
(1.00)\end{array}$ & $\begin{array}{l}0.026 \\
(0.08)\end{array}$ & $\begin{array}{r}-0.337 \\
(0.96)\end{array}$ & $\begin{array}{r}-0.482 \\
(1.52)\end{array}$ & $\begin{array}{c}-0.831 * * \\
(2.31)\end{array}$ \\
\hline Utilities and construction & $\begin{array}{l}0.134 \\
(1.07)\end{array}$ & $\begin{array}{l}0.366^{* * * *} \\
(2.81)\end{array}$ & $\begin{array}{l}0.412 * * * \\
(3.19)\end{array}$ & $\begin{array}{l}0.169 \\
(1.29)\end{array}$ & $\begin{array}{c}-0.294^{* *} \\
(2.12)\end{array}$ & $\begin{array}{c}0.277 * * \\
(2.21)\end{array}$ & $\begin{array}{c}0.281 * * \\
(1.97)\end{array}$ \\
\hline Sales hotel & $\begin{array}{l}0.032 \\
(0.66)\end{array}$ & $\begin{array}{c}0.223 * * * \\
(4.46)\end{array}$ & $\begin{array}{l}0.035 \\
(0.70)\end{array}$ & $\begin{array}{c}-0.083 * \\
(1.66)\end{array}$ & $\begin{array}{c}-0.230 * * * \\
(4.33)\end{array}$ & $\begin{array}{c}0.194 * * * \\
(4.02)\end{array}$ & $\begin{array}{r}-0.066 \\
(1.22)\end{array}$ \\
\hline Transport & $\begin{array}{c}-0.195^{*} \\
(1.86)\end{array}$ & $\begin{array}{l}0.029 \\
(0.26)\end{array}$ & $\begin{array}{l}0.038 \\
(0.35)\end{array}$ & $\begin{array}{r}-0.079 \\
(0.72)\end{array}$ & $\begin{array}{c}-0.211^{*} \\
(1.81)\end{array}$ & $\begin{array}{l}0.089 \\
(0.84)\end{array}$ & $\begin{array}{l}-0.414 * * * \\
(3.46)\end{array}$ \\
\hline Finance property & $\begin{array}{c}-0.199 * * * \\
(3.50)\end{array}$ & $\begin{array}{l}0.085 \\
(1.43)\end{array}$ & $\begin{array}{c}-0.161 * * * \\
(2.73)\end{array}$ & $\begin{array}{c}-0.126^{* *} \\
(2.11)\end{array}$ & $\begin{array}{c}-0.248 * * * \\
(3.93)\end{array}$ & $\begin{array}{l}0.052 \\
(0.91)\end{array}$ & $\begin{array}{c}-0.368 * * * \\
(5.67)\end{array}$ \\
\hline Other industry & $\begin{array}{c}-0.145^{* *} \\
(2.28)\end{array}$ & $\begin{array}{l}0.219^{* * *} \\
(3.30)\end{array}$ & $\begin{array}{c}-0.157 * * \\
(2.39)\end{array}$ & $\begin{array}{c}-0.188 * * * \\
(2.81)\end{array}$ & $\begin{array}{r}-0.099 \\
(1.40)\end{array}$ & $\begin{array}{l}0.284 * * * \\
(4.43)\end{array}$ & $\begin{array}{l}-0.275^{* * *} \\
(3.80)\end{array}$ \\
\hline Firm size: & & & & & & & \\
\hline Firm size 5-19 & $\begin{array}{r}-0.044 \\
(0.96)\end{array}$ & $\begin{array}{c}-0.246 * * * \\
(5.13)\end{array}$ & $\begin{array}{c}-0.095 * * \\
(1.99)\end{array}$ & $\begin{array}{c}-0.130 * * * \\
(2.69)\end{array}$ & $\begin{array}{r}-0.066 \\
(1.29)\end{array}$ & $\begin{array}{c}-0.217 * * * \\
(4.68)\end{array}$ & $\begin{array}{c}-0.219 * * * \\
(4.17)\end{array}$ \\
\hline Firm size 20-99 & $\begin{array}{c}-0.125^{* *} \\
(2.56)\end{array}$ & $\begin{array}{c}-0.297 * * * \\
(5.81)\end{array}$ & $\begin{array}{c}-0.281 * * * \\
(5.53)\end{array}$ & $\begin{array}{c}-0.153 * * * \\
(2.97)\end{array}$ & $\begin{array}{c}-0.211 * * * \\
(3.88)\end{array}$ & $\begin{array}{c}-0.297 * * * \\
(6.01)\end{array}$ & $\begin{array}{c}-0.349 * * * \\
(6.25)\end{array}$ \\
\hline Firm size $100-499$ & $\begin{array}{r}-0.069 \\
(1.16)\end{array}$ & $\begin{array}{c}-0.380 * * * \\
(6.09)\end{array}$ & $\begin{array}{c}-0.362 * * * \\
(5.84)\end{array}$ & $\begin{array}{c}-0.195 * * * \\
(3.10)\end{array}$ & $\begin{array}{c}-0.337 * * * \\
(5.07)\end{array}$ & $\begin{array}{c}-0.370 * * * \\
(6.13)\end{array}$ & $\begin{array}{l}-0.502 * * * \\
(7.36)\end{array}$ \\
\hline Firm size $500+$ & $\begin{array}{c}-0.154 * * \\
(2.10)\end{array}$ & $\begin{array}{c}-0.307 * * * \\
(4.01)\end{array}$ & $\begin{array}{c}-0.374 * * * \\
(4.91)\end{array}$ & $\begin{array}{l}-0.045 \\
(0.58)\end{array}$ & $\begin{array}{c}-0.257 * * * \\
(3.16)\end{array}$ & $\begin{array}{c}-0.484 * * * \\
(6.54)\end{array}$ & $\begin{array}{c}-0.516^{* * *} \\
(6.16)\end{array}$ \\
\hline Year dummies & & & & & & & \\
\hline Constant & $\begin{array}{c}2.506^{* * * *} \\
(13.38)\end{array}$ & $\begin{array}{c}2.967^{* * *} \\
(15.16)\end{array}$ & $\begin{array}{c}3.736^{* * *} \\
(19.22)\end{array}$ & $\begin{array}{c}3.876^{* * *} \\
(19.68)\end{array}$ & $\begin{array}{c}3.612 * * * \\
(17.35)\end{array}$ & $\begin{array}{c}3.732 * * * \\
(19.74)\end{array}$ & $\begin{array}{c}4.329 * * * \\
(20.23)\end{array}$ \\
\hline Observations & 5847 & 5847 & 5847 & 5847 & 5847 & 5847 & 5847 \\
\hline R-squared & 0.12 & 0.28 & 0.09 & 0.13 & 0.05 & 0.05 & 0.04 \\
\hline
\end{tabular}

Source: Author's own calculations from ECHP 1995-2001;

Absolute value of $\mathrm{t}$ statistics in parentheses * significant at $10 \%$; * significant at $5 \%$; *** significant at $1 \%$. 
When we move into the working hours dummy variable two facts deserve our attention. On the one hand, those men and women working more than 40 hours per week report less satisfaction with number of working hours, working times, working conditions and distance to job than the reference workers (those working 40 hours or fewer). On the other hand, satisfaction with earnings and job security get higher for men who works over 40 hours per week, while it does not show a significant coefficient in the case of female workers. This observed difference might help to understand why men work longer hours than women and, consequently, devote less time to family commitments. In recent years working hours has become an important policy issue in debates over both potential threats for Europe's high unemployment and overwork (mainly focused on the negative consequences on worker's health status). Accordingly it seems that working hours is a potentially useful policy instrument to change workers satisfaction.

Turning to our findings, we find a consistent positive effect of permanent contracts on job satisfaction. Similarly, being supervisor correlates positively with most job satisfaction sides, yet female workers behave slightly different on this. Above all, women with supervisory responsibilities are less satisfied with working hours as compared to those who do not supervise, possibly because they have to devote marginally longer hours to work and consequently are left with less time for family tasks.

Marital status coefficient is significant for men and women, when satisfaction with earnings is evaluated, although with opposite signs. This may respond to the fact that marital status is more linked to being the head of household for men than for women, which means a stronger pressure for men to get a higher wage if married. However both seem to be less satisfied with working hours than single people.

The last variable related to family status is a dummy variable to control for having children below school entry age. The coefficient is negative, and this reinforces the argument about the difficulties that couples find to reconcile professional and family life. On the contrary, being in good health increases workers' satisfaction.

It is noticeable that, ceteris paribus, longer previous unemployment spells tend to slightly reduce job satisfaction of male workers, perhaps because the extent of this previous labour mismatch constraints workers' opportunities to sort themselves into the jobs which offer the rewards that they value highly. 
There is little variation by sex in the effect of regional unemployment rates. Higher surrounding unemployment makes workers more satisfied in being employed and consequently more satisfied with earnings and job security.

The final set of variables measures the size of the firm where the individual is currently working. Basically, small firms (family firms) grant higher levels of satisfaction to workers.

So far, we have centered our attention in the econometric analysis of the data. This analysis has allowed us to find significant relations between the different satisfaction levels and the variables considered, which in turn provide some interesting conclusions about the structure of the Spanish labour market. Now, we consider the possibility of going a step forward: the optimization phase. Namely, we would like to give answers to the following questions: what is the profile of the most satisfied Spanish worker? and, which policies can be carried out in order to increase the workers' satisfaction? In order to answer these questions, a multiobjective model has been built, whose elements are defined in what follows.

\subsection{Multiobjective Analysis.}

\subsubsection{Data.}

Although not all the variables considered in the econometric study described in section 3.2 are controllable by any decision maker, to answer the first question above stated we will consider all of them as decision variables for the multiobjective model. Therefore, the decision variables of the model are the 29 variables described in Table 1, plus 6 instrumental year dummy variables. As previously highlighted, 4 of these variables are continuous ( $g h w g$, netfipc, unemdur and regunem), while the rest are binary.

\subsubsection{Objective functions.}

The objective to be considered in this study is the workers's satisfaction, which has been in turn divided into 7 satisfaction categories. The econometric study has allowed us to express these levels as functions of the variables, with the linear coefficients shown in tables 3 (for men) and 4 (for women). Therefore, if we rename the variables as $x_{i}, i=1, \ldots, 35$ (only in this section, for the sake of clarity), $\hat{\mathrm{B}}_{i}^{j}$ is the regression coefficient of variable $i$ for satisfaction level $j$, and $\mathrm{A}^{j}$ is the independent term of satisfaction level $j$, then we have the following 7 objectives: 


$$
E S_{j}(\mathbf{x}) \quad \hat{\mathrm{A}}^{j} \quad \sum_{i=1}^{35} \hat{\mathrm{B}}_{i}^{j} x_{i}, \quad j \quad 1, \cdots, 7
$$

which measure the expected satisfaction levels with respect to earnings, job security, type of work, number of working hours, working times, working conditions/ environment and distance to job, respectively.

\subsubsection{Constraints.}

Let us now define the set of constraints of the model. In this section, only the values for men are shown, but the corresponding model for women has also been developed ${ }^{5}$. First, there is a set of technical constraints which assure that certain binary variables do not take the value 1 simultaneously. Let us remind that the reference value of each group (which is assumed to equal 1 if the rest equal 0 ) is not considered as a variable, and that is why the following constraints are inequalities:

๘ Education level:

$$
\text { edhigher edsec } \beta 1
$$

๘ Seniority:

$$
\text { jobten } 34 \text { jobten59 jobten } 1014 \text { jobten } 15 \beta 1
$$

Ф Occupational status:

$$
\text { supervisory intermediate } \beta 1
$$

๘ Health status:

$$
\text { goodhealth fairhealth } \beta 1
$$

๘ Industry:

$$
\text { ind } 1 \text { ind } 3 \text { ind } 4 \text { ind } 5 \text { ind } 6 \text { ind } 7 \beta 1
$$

Ф Firm size:

$$
f_{s} 519 f_{s} 2099 \quad f_{s} 100499 \quad f_{s} 500 \beta 1
$$

๘ Year dummies:

\footnotetext{
${ }^{5}$ Available from the authors upon request.
} 


$$
\text { year2 year3 year } 4 \text { year } 5 \text { year6 year } 7 \beta 1
$$

Next, three more constraints have been considered, based on logical and/or technical relations among some of the variables.

Ф Age, seniority and unemployment duration. The sum of the job seniority plus the unemployment duration cannot be greater than the worker's age minus 16, which is the minimum age considered for starting to work (note that unemdur is measured in months):

age $\quad 3$ jobten $34 \quad 5$ jobten $59 \quad 10$ jobten $1014 \quad 15$ jobten $15 \quad \frac{1}{12}$ unmedur $\rho 16$

Ф Salary and education level. On the basis of the data, we have considered upper bounds on the salary for the different education levels:
(a) If edsec 0 then $g h w g \beta 22.16$
(b) If edsec 1 then ghwg $\beta 17.64$
(c) If edhig edsec 0 then ghwg $\beta 12.38$
(d) If edhig edsec 1 then ghwg $\beta 22.16$

These bounds are reflected in the two following constraints:

$$
\begin{gathered}
\text { ghwg (22.16 17.64) edsecsec } \beta 22.16 \\
\text { ghwg (22.16 12.38) (edhigher edsecsec) } \beta 12.38
\end{gathered}
$$

๘ Salary and Occupational status. Again, we have considered upper bounds on the salary for the different occupational statuses:

(a) If intermediate $\quad 0$ then ghwg $\beta 26.09$

(b) If intermediate 1 then ghwg $\beta 18.35$

(c) If supervisory intermediate 0 then ghwg $\beta 12.99$

(d) If supervisory intermediate 1 then ghwg $\beta 26.09$

These bounds are reflected in the two following constraints:

$$
\begin{array}{cccc} 
& \text { ghwg } & (26.09 & 18.35) \text { intermediate } \beta 26.09 \\
\text { ghwg } & (26.09 & 12.99) & \text { (supervisory intermediate) } \beta 12.99
\end{array}
$$


Finally, some other constraints have been derived from linear regression analysis. Namely, we have chosen pairs of variables whose dependencies are stronger according to such analysis, and thus it is not realistic to let them take independent values. In order to build these two-sided constraints, we have used the $98 \%$ confidence intervals:

$\varpi$ Dependency between edhigher and ghwg. The linear regression is given by:

$$
\text { ghwg A married B }
$$

where the confidence intervals of the coefficients are (98\%):

$$
\text { A ;2.787, 3.1514= and B ;6.285, 6.4564= }
$$

which implies

$$
\begin{aligned}
& \text { ghwg } 3.1514 \text { edhigher } 6.4564 \beta 0 \\
& \text { ghwg } 2.787 \text { edhigher } 6.285 \rho 0
\end{aligned}
$$

๘ Dependency between netfipc and married. The linear regression is given by:

$$
\text { netfipc A married B }
$$

where the confidence intervals of the coefficients are (98\%):

$$
\text { A ; 6.404, 5.779= and B ;9.503, 9.975= }
$$

which implies

$$
\begin{aligned}
& \text { netfipc } 5.779 \text { married } 9.975 \beta 0 \\
& \text { netfipc } 6.404 \text { married } 9.503 \rho 0
\end{aligned}
$$

$\varpi$ Dependency between married and age. The linear regression is given by:

$$
\text { married A age } \mathrm{B}
$$

where the confidence intervals of the coefficients are (98\%):

$$
\text { A } ; 0.02603,0.0279=\text { and } \mathrm{B} \quad ; \quad 0.3733,0.3076=
$$

which implies

$$
\begin{array}{ll}
\text { married } & 0.0279 \text { age } 0.3076 \beta 0 \\
\text { married } & 0.02603 \text { age } 0.3733 \rho 0
\end{array}
$$

$\varpi$ Dependency between regunem and age. The linear regression is given by: 
regunem A age $\mathrm{B}$

where the confidence intervals of the coefficients are (98\%):

A ; $0.4082, \quad 0.3741=$ and $\mathrm{B} \quad ; 26.7037,27.9013=$

which implies

$$
\begin{aligned}
& \text { regunem } 0.3741 \text { age } 27.9013 \beta 0 \\
& \text { regunem } 0.4082 \text { age } 26.7037 \rho 0
\end{aligned}
$$

Therefore, the model has a total of $20(=8+4+8)$ technical constraints. Thus, the multiobjective problem to be solved is the following:

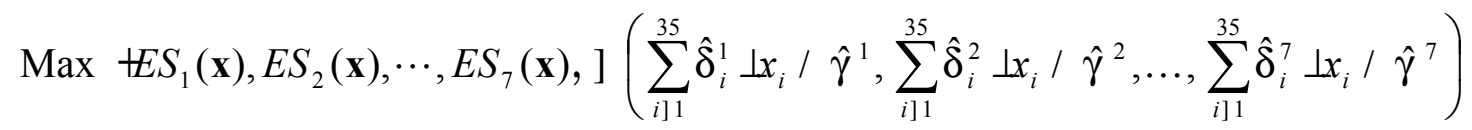

Subject to:

$$
\text { Constraints }(\mathrm{C} 1)-(\mathrm{C} 20) \text {, }
$$

Variables bounds types defined in Table 1 (Appendix).

Thus, the model under evaluation is a mixed integer linear multiobjective model with 7 objectives, 20 constraints and several simple bounds and integrality constraints.

\section{Resolution of the Problem.}

The multiobjective problem has been solved in two phases. First, we intend to detect the profile of the "most satisfied" Spanish worker. To this end, we have used a Reference Point approach, where the Danish mean satisfaction levels have been used as reference level, that is, for men:

$$
q_{1} \quad 4.31, \quad q_{2} 4.82, \quad q_{3} 4.85, \quad q_{4} \quad 4.85, \quad q_{5} \quad 4.99, \quad q_{6} \quad 4.76, \quad q_{7} 4.89
$$

and for women,

$$
q_{1} \quad 4.36, q_{2} \quad 4.74, \quad q_{3} \quad 4.78, \quad q_{4} \quad 4.76, \quad q_{5} \quad 4.92, \quad q_{6} \quad 4.80, \quad q_{7} 4.89
$$

Consequently the reference point problem solved in both cases is:

\section{Min A}

Subject to: 


$$
\begin{aligned}
& q_{j}\left(\begin{array}{lll}
\sum_{i=1}^{35} \hat{\mathrm{B}}_{i}^{j} & x_{i} & \hat{\mathrm{A}}^{j}
\end{array}\right) \beta \mathrm{A} \\
& \text { Constraints }(\mathrm{C} 1)-(\mathrm{C} 20), \\
& \text { Variables bounds types defined in Table } 1 .
\end{aligned}
$$

Note that, given that all the satisfaction levels are specified in a $1-6$ scale, no normalization is necessary in this formulation. The solutions obtained for both men and

\begin{tabular}{|c|c|c|c|c|c|}
\hline \multicolumn{6}{|c|}{ Decision Variables } \\
\hline \multirow{2}{*}{ Names } & \multicolumn{2}{|c|}{ Solution } & \multirow{2}{*}{ Names } & \multicolumn{2}{|c|}{ Solution } \\
\hline & Men & Women & & Men & Women \\
\hline Earnings & 9.61 & 7.98 & Unemployment duration & 0 & 38 \\
\hline Higher education & 1 & 1 & Good health & 1 & 1 \\
\hline Secondary education & 0 & 0 & Fair health & 0 & 0 \\
\hline Net Family Income $\left(10^{3} \square\right.$ & $1 / 4 \square 4.2$ & 9.5 & Regional unemployment rate & 9.95 & 16.79 \\
\hline Age & 48 & 51.61 & Mining and quarrying & 0 & 0 \\
\hline Seniority 3-4 & 0 & 0 & Utilities and construction & 0 & 0 \\
\hline Seniority 5-9 & 0 & 0 & Sales hotel & 0 & 1 \\
\hline Seniority $10-14$ & 0 & 0 & Transport & 0 & 0 \\
\hline Seniority $15+$ & 0 & 0 & Finance property & 0 & 0 \\
\hline Working +40 hours/week & 0 & 0 & Other industry & 1 & 0 \\
\hline Permanent contract & 1 & 1 & Firm size 5-19 & 0 & 0 \\
\hline Supervisory & 1 & 1 & Firm size 20-99 & 0 & 0 \\
\hline Intermediate & 0 & 0 & Firm size $100-499$ & 0 & 0 \\
\hline Married & 1 & 1 & Firm size $500+$ & 1 & 0 \\
\hline Children $<6$ & 0 & 1 & & & \\
\hline
\end{tabular}
women are shown in Table 5.

Table 5. Solutions for the first model.

\begin{tabular}{|c|c|c|c|c|}
\hline \multirow{2}{*}{ Satisfaction } & \multicolumn{2}{|c|}{ Men } & \multicolumn{2}{|c|}{ Women } \\
\hline & Value & Reference & Value & Reference \\
\hline 1 & 3.93 & 4.31 & 3.72 & 4.36 \\
\hline 2 & 4.74 & 4.82 & 4.94 & 4.74 \\
\hline 3 & 4.85 & 4.85 & 5.16 & 4.78 \\
\hline 4 & 4.45 & 4.85 & 4.48 & 4.76 \\
\hline 5 & 4.50 & 4.99 & 4.28 & 4.92 \\
\hline 6 & 4.69 & 4.76 & 5.04 & 4.80 \\
\hline 7 & 4.54 & 4.89 & 4.86 & 4.89 \\
\hline
\end{tabular}

Objective functions

Source: Author's own calculations from ECHP 1995-2001.

The results presented in Table 5 provide a "taxonomy" of the most satisfied Spanish male and female workers. Both, men and women, need "high" real hourly wages to be cataloged in the group of the most satisfied. To be precise we refer to those workers in the top quartile of the earnings distribution. In the same vein, higher education seems to be the highest educational level required to enjoy this soaring satisfaction status. This link deserves 
special attention as it introduces an important nuance to the results presented in Section 3.2, where the satisfaction levels were observed to decrease with the education level. Therefore the multiobjective analysis has allowed us to find the relations between variables (in this case, salary and level of education), and the solution indicates that, despite the negative relation between the level of education and the satisfaction levels, the impact of the former on the salary leads the optimal profile to a worker with higher level.

Interestingly, attending to our results middle-aged workers are more satisfied than young and elderly people, maybe as a consequence of reaching certain degree of balance between physiological matureness (or working experience) and good enough physical conditions to enjoy their jobs.

Net family income above the mean is crucial to women job satisfaction, on the contrary men with net family income far below the mean are also among the most satisfied. This giving further support to the argument stated in Section 3.2.

Regardless of workers' sex, working less than 40 hours, having a permanent contract and supervisory responsibilities are all factors providing job satisfaction.

The solutions for the family status variables make clear that married people get higher in the job satisfaction scale but only married women having young children do.

Due to the disadvantaged position of women as compared to men in the labour market, female workers accept worse levels of previous individual unemployment and actual regional unemployment as satisfactory.

Good health conditions are important for both, men and women, in order to enjoy their jobs, reinforcing the argument above mentioned on the importance of good mental and physical conditions. Finally, male workers apparently prefer big firms as opposed to small business, which is the women's case.

With respect to the satisfaction levels of the final solution, women achieve three out of their seven reference levels (job security, type of work and working conditions), while men only achieve one (type of work). But, on the other hand, the highest unachievement corresponds also to women (0.64 in earnings level and working times), while for men the highest unachievement is 0.49 (working times). Thus, the final solution for women seems to be slightly more unbalanced, reflecting the general worse labour conditions of women in Spain. 
Nevertheless, in this solution it can be observed that the constraints stemming from linear regressions of the econometric analysis (C13-C20) are constraining certain variables (namely, hourly wage, net family income and regional unemployment rate) to stay within the limits imposed by the current situation. Therefore, it would be interesting to let some relaxation in these constraints, so as to determine what kind of policies may be implemented in order to increase workers' satisfaction levels. Namely, the constraints to be relaxed are C13, C15 and C19, which are binding at the current solution. But the relaxation of these constraints is penalized, so that we are trying to find a tradeoff between this relaxation, and its effect on the workers' satisfaction. To this end, a Goal Programming approach has been combined with the previous Reference Point scheme. Constraint 13 has been substituted by the two following constraints:

$$
\begin{gathered}
\text { ghwg } 3.1514 \text { edhigher } 6.4564 p_{13} \beta 0 \\
\frac{1}{31.3272} p_{13} \beta \mathrm{B}
\end{gathered}
$$

That is, $p_{13}$ is the non desired deviation variable, which measures how much has the constraint been violated. In $\mathrm{C} 13 \mathrm{~b}, p_{13}$ is normalized dividing it by the maximum observed value of $g h w g$, so that it can be afterwards included in the objective function. Using the same scheme, the following constraints are formulated:

$$
\begin{array}{ccc}
\text { netfipc } & 5.779 \text { married } 9.975 p_{15} \beta 0 \\
& \frac{1}{136.2609} p_{15} \beta \mathrm{B} & \\
\text { regunem } & 0.3741 \text { age } 27.9013 & p_{19} \beta 0 \\
\frac{1}{46.1} p_{19} & \beta \mathrm{B}
\end{array}
$$

In practice, violating constraint $\mathrm{C} 13$ means to increase the mean salary of the workers with higher education level, violating C15 means to increase the family income of married workers, and violating $\mathrm{C} 19$ means an increase of the regional unemployment rate.

Therefore, the problem to be solved at this second stage is:

$\operatorname{Min} \frac{1}{6} \mathrm{~A} \quad \mathrm{MB}$

Subject to: 


$$
\begin{aligned}
& q_{j}\left(\begin{array}{lll}
\sum_{i=1}^{35} \hat{\mathrm{B}}_{i}^{j} & x_{i} & \hat{\mathrm{A}}^{j}
\end{array}\right) \beta \mathrm{A} \\
& \text { Constraints }(\mathrm{C} 1)-(\mathrm{C} 12) \text {, } \\
& \text { (C13a), (C13b) } \\
& \text { (C14) } \\
& \text { (C15a), (C15b) } \\
& \text { (C16) - (C18) } \\
& \text { (C19a), (C19b) }
\end{aligned}
$$

Variables bounds types defined in Table 1 (Appendix).

Note that the penalization on the undesired deviation variables has been included in the objective function, together with the achievement scalarizing function. To this end, A has been normalized by dividing it by 6 , which is the maximum value of the satisfaction scale. This way, both terms mean "proportion of the maximum value" and they can be combined. On the other hand, Mis a control parameter which lets us to weight the relative importance of the constraints violation. This problem has been solved (for both men and women) for several values of the parameter $\mathrm{M}$ The solution for $\mathrm{M}=1$ was the same as the one obtained before (Table 5), which means that, if the same importance is given to the achievement of the reference values and to the violation of the constraints, it is not worth to relax such constraints in order to increase the satisfaction levels. The solution changes for other values of M In particular, the solutions for $\mathrm{M}=0.7$ and $\mathrm{M}=0.4$ are given in Tables 6 and 7, respectively.

In Table 6, the following aspects can be highlighted. With respect to the satisfaction levels, men have increased all of them except the distance to work, which has decreased very slightly. Two reference levels are now achieved (job security and type of work), and the maximum unachievement is now 0.39 (working times). The situation for women, as compared with the solution showed in Table 5, is slightly different. Type of work and working conditions are still achieved, but the reference level for job security is not achieved now, and only two satisfaction levels have been increased (earnings and working times), while the rest have been decreased. However, the maximum unachievement has decreased to 0.41 (earnings and working hours). This result means that the solution for women is now more balanced than the one obtained before. With respect to the values of the variables, for both men and women, salary $(g h w g)$, net family income (netfipc) and regional unemployment rate (regunem) would have increased significantly. Besides, for women, the unemployment 
duration (unemdur) has also increased, not having children under 6 is now preferred, and the industrial sector has changed from sales, hotels and restaurants to manufacturing. All these results have been achieved with a small violation of the constraints (B equals 0.06 for men and 0.04 for women); which means that it should be possible to obtain it with "small" structural changes. We have to stress that some commentators may argue that increasing wage and family income are achievable, under particular economic conditions, and socially profitable targets. However, higher regional unemployment rates, although "easily" attainable, are totally unacceptable from the point of view of the Welfare State and the related social policies. Obviously policy makers concerned with the use of the results stemming from these techniques should interpret them with caution in the case of macro-economic variables, as is the case of the regional unemployment rate. It is so because this variable is used just as a reference for workers, which due to their employment status feel themselves happier in a context of higher unemployment rates. But, by no way means that higher unemployment rates should be a target.

Table 6. Solutions for the second model, and $\mathrm{M}=0.7$.

\begin{tabular}{|c|c|c|c|c|c|c|}
\hline \multicolumn{7}{|c|}{ Decision Variables } \\
\hline \multirow{2}{*}{ Names } & \multicolumn{2}{|c|}{ Solution } & \multirow{2}{*}{\multicolumn{2}{|c|}{ Names }} & \multicolumn{2}{|c|}{ Solution } \\
\hline & Men & Women & & & Men & Women \\
\hline Earnings & 11.54 & 9.33 & \multicolumn{2}{|c|}{ Unemployment duration } & 0 & 43.00 \\
\hline Higher education & 1 & 1 & \multicolumn{2}{|c|}{ Good health } & 1 & 1 \\
\hline Secondary education & 0 & 0 & \multicolumn{2}{|l|}{ Fair health } & 0 & 0 \\
\hline Net Family Income $\left(10^{3} \square\right.$ & $1 / 4 \square 2.61$ & 19.53 & \multicolumn{2}{|c|}{ Regional unemployment rate } & 12.79 & 19.22 \\
\hline Age & 48.00 & 51.61 & \multicolumn{2}{|c|}{ Mining and quarrying } & 0 & 0 \\
\hline Seniority 3-4 & 0 & 0 & \multicolumn{2}{|c|}{ Utilities and construction } & 0 & 0 \\
\hline Seniority 5-9 & 0 & 0 & \multicolumn{2}{|c|}{ Sales hotel } & 0 & 0 \\
\hline Seniority $10-14$ & 0 & 0 & \multicolumn{2}{|l|}{ Transport } & 0 & 0 \\
\hline Seniority $15+$ & 0 & 0 & \multicolumn{2}{|c|}{ Finance property } & 0 & 0 \\
\hline Working +40 hours/week & 0 & 0 & \multicolumn{2}{|c|}{ Other industry } & 1 & 0 \\
\hline Permanent contract & 1 & 1 & \multicolumn{2}{|c|}{ Firm size 5-19 } & 0 & 0 \\
\hline Supervisory & 1 & 1 & \multicolumn{2}{|c|}{ Firm size 20-99 } & 0 & 0 \\
\hline Intermediate & 0 & 0 & \multicolumn{2}{|c|}{ Firm size $100-499$} & 0 & 0 \\
\hline Married & 1 & 1 & \multicolumn{2}{|c|}{ Firm size 500+ } & \multirow{2}{*}{\multicolumn{2}{|c|}{0}} \\
\hline Children $<6$ & 0 & 0 & & & & \\
\hline \multicolumn{7}{|c|}{ Objective functions } \\
\hline \multirow{2}{*}{ Satisfaction } & \multicolumn{3}{|c|}{ Men } & \multicolumn{3}{|c|}{ Women } \\
\hline & Value & & Reference & Value & Ret & ference \\
\hline 1 & 4.20 & & 4.31 & 3.95 & & 4.36 \\
\hline 2 & 4.82 & & 4.82 & 4.72 & & 4.74 \\
\hline 3 & 4.87 & & 4.85 & 4.90 & & 4.78 \\
\hline 4 & 4.50 & & 4.85 & 4.35 & & 4.76 \\
\hline 5 & 4.60 & & 4.99 & 4.66 & & 4.92 \\
\hline 6 & 4.74 & & 4.76 & 4.85 & & 4.80 \\
\hline 7 & 4.52 & & 4.89 & 4.71 & & 4.89 \\
\hline
\end{tabular}

Source: Author's own calculations from ECHP 1995-2001. 
On the other hand, the results displayed in Table 7 can be regarded as utopic, or, at least, targets for a long term horizon. In this case, the violations are much higher (B equals 0.25 for men and 0.15 for women), which means much deeper changes. In the final solution, all the reference levels for men have been achieved, while for women only two are not achieved (earnings and working times), but with very small differences (0.05 and 0.04, respectively). With respect to the variables salary ( $g h w g$ ), net family income (netfipc) and regional unemployment rate (regunem), they have again been significantly increased. Besides, occupational status has changed from supervisory to intermediate and the option of having children under age 6 is again more desirable.

Table 7. Solutions for the second model, and $\mathrm{M}=0.4$.

\begin{tabular}{|c|c|c|c|c|c|c|}
\hline \multicolumn{7}{|c|}{ Decision Variables } \\
\hline \multirow{2}{*}{ Names } & \multicolumn{2}{|c|}{ Solution } & \multirow{2}{*}{\multicolumn{2}{|c|}{ Names }} & \multicolumn{2}{|c|}{ Solution } \\
\hline & Men & Women & & & Men & Women \\
\hline Earnings & 17.38 & 12.67 & \multicolumn{2}{|c|}{ Unemployment duration } & 0 & 43.00 \\
\hline Higher education & 1 & 1 & \multicolumn{2}{|c|}{ Good health } & 1 & 1 \\
\hline Secondary education & 0 & 0 & \multicolumn{2}{|c|}{ Fair health } & 0 & 0 \\
\hline Net Family Income $\left(10^{3} \square\right.$ & $1 / 432.87$ & 36.60 & \multicolumn{3}{|c|}{ Regional unemployment rate 21.39} & 25.25 \\
\hline Age & 48.00 & 51.61 & \multicolumn{2}{|c|}{ Mining and quarrying } & 0 & 0 \\
\hline Seniority 3-4 & 0 & 0 & \multicolumn{2}{|c|}{ Utilities and construction } & 0 & 1 \\
\hline Seniority 5-9 & 0 & 0 & \multicolumn{2}{|c|}{ Sales hotel } & 0 & 0 \\
\hline Seniority $10-14$ & 0 & 0 & \multicolumn{2}{|c|}{ Transport } & 0 & 0 \\
\hline Seniority $15+$ & 0 & 0 & \multicolumn{2}{|c|}{ Finance property } & 0 & 0 \\
\hline Working +40 hours/week & 0 & 0 & \multicolumn{2}{|c|}{ Other industry } & 1 & 0 \\
\hline Permanent contract & 1 & 1 & \multicolumn{2}{|c|}{ Firm size 5-19 } & 0 & 0 \\
\hline Supervisory & 1 & 0 & \multicolumn{2}{|c|}{ Firm size 20-99 } & 0 & 0 \\
\hline Intermediate & 0 & 1 & \multicolumn{2}{|c|}{ Firm size $100-499$} & 0 & 0 \\
\hline Married & 1 & 1 & \multirow{2}{*}{\multicolumn{2}{|c|}{ Firm size $500+$}} & \multirow{2}{*}{\multicolumn{2}{|c|}{0}} \\
\hline Children $<6$ & 0 & 1 & & & & \\
\hline \multicolumn{7}{|c|}{ Objective functions } \\
\hline \multirow{2}{*}{ Satisfaction } & \multicolumn{3}{|c|}{ Men } & \multicolumn{3}{|c|}{ Women } \\
\hline & Value & & Reference & Value & & eference \\
\hline 1 & 4.70 & & 4.31 & 4.31 & & 4.36 \\
\hline 2 & 5.00 & & 4.82 & 5.08 & & 4.74 \\
\hline 3 & 5.18 & & 4.85 & 5.33 & & 4.78 \\
\hline 4 & 4.89 & & 4.85 & 4.92 & & 4.76 \\
\hline 5 & 5.21 & & 4.99 & 4.88 & & 4.92 \\
\hline 6 & 5.27 & & 4.76 & 5.29 & & 4.80 \\
\hline 7 & 4.98 & & 4.89 & 4.89 & & 4.89 \\
\hline
\end{tabular}

Source: Author's own calculations from ECHP 1995-2001.

In brief, the relaxation of some constraints may help to understand the scope for some flexibility in terms of achievable targets. In this sense it appears that male workers are in an outstanding position, as compared to women, to achieve relatively higher satisfaction levels. 
In other words there are some idiosyncratic factors binding women's opportunities to improve their satisfaction with earnings and working times that may be referred to as discriminatory factors in the labour market.

\section{Conclusions.}

In this paper, a multiobjective analysis has been carried out as a complement to an econometric study regarding workers' satisfaction in the Spanish labour market. Once the econometric analysis has allowed us to determine the relations between several variables and the workers' satisfaction levels, the ulterior multicriteria approach has enabled a further consideration of the conflicts between the different satisfaction levels, and the impact on such levels of the most significant variables. This combination of methodologies has proved to be useful for the identification of the desirable profiles for Spanish workers, as well as the determination of policies that may be carried out in order to improve worker's satisfaction. Also from the methodological point of view, the joint use of a Reference Point scheme and a Goal Programming approach has facilitate to maintain the original reference levels, while allowing certain flexibility on some of the original constraints, so as to determine which kind of structural changes should be carried out.

Regarding the results obtained, it can be concluded that the profile of the most satisfied workers in Spain is that of a middle-aged person with high incomes (situated in the top quartile), and with higher education level. In this sense, it is important to highlight that the multicriteria analysis has led us to the conclusion that while the education level, when considered independently from other variables, is a negative factor for the satisfaction, its impact on other variables makes higher education desirable. It is also worth to emphasize that family income is much more important for women satisfaction than for men. The second phase of the multicriteria analysis has produced more balanced solutions, especially in the case of women, which means that the current situation of the Spanish labour market is much more negative for women, who need deeper structural changes to increase their satisfaction. In general, higher incomes (salary and family income) are needed to achieve higher satisfaction levels, but there is another important factor: a great part of the current satisfaction levels is derived from the high unemployment rates. That is, workers are more satisfied from actually having a job in regions with a high unemployment situation. This conclusion has been especially evident in the second phase of our analysis. 
Finally, let us point out that, in our opinion, this kind of study would be a very useful tool in order to keep track of the evolution of the labour market, if carried out several times along a given planning period, because it can determine which factors are being more decisive for workers' satisfaction, which policies have been successful, and which ones should be reinforced.

\section{References.}

ALVES, M.J. and CLIMACO, J. (2004). "A note on a decision support system for multiobjective integer and mixed-integer programming problems", European Journal of Operational Research, Vol.155, No.1, pp.258-265.

CABAllero, R., LUQUE, M., MOLINA, J. and RUIZ, F (2002). "PROMOIN: An Interactive System for Multiobjective Programming", International Journal of Information Technologies and Decision Making, Vol.1, pp.635-656.

CABALLERO, R., REY, L. and RUIZ, F. (1996). "Determination of Satisfying and Efficient Solutions in Convex Multi-Objective Programming”, Optimization, Vol.37, pp.125-137. CLARK, A. E. (2005). "Your Money or Your Life: Changing Job Quality in OECD Countries", IZA Discussion Paper, No.1610, 2005.

CLARK, A.E. and OSWALD, A.J. (1996) "Satisfaction and comparison income", Journal of Public Economics, Vol.61, pp.359-381.

FREEMAN, R.B. (1978). "Job satisfaction as an economic variable", American Economic Review, Vol.68, pp.135-141.

GAMERO, C. (2005). Microeconomic Analysis of labour Satisfaction (In Spanish), Consejo Económico y Social, Colección Estudios, Madrid.

LEONTARIDI, R. and SLOANE, P. (2001). "Measuring the Quality of Jobs: Promotion Prospects, Low Pay and Job Satisfaction”, LoWER Working Paper No07, University of Amsterdam, 2001.

LUQUE, M., CABALLERO, R., MOLINA, J. and RUIZ, F. (2007).”Equivalent Information for Multiobjective Interactive Procedures”, Management Science, Vol.53 (1), 125-134, 2007.

MIETTINEN, K. (1999). Nonlinear Multiobjective Optimization, Kluwer Academic Publishers, Boston.

NAG C (2000). Library Manual, Mark 6, NAG (Numerical Algorithm Group Limited) Ltd, Oxford. 
PERACCHI, F. (2002). “The European Community Household Panel: a Review”, Empirical Economics, Vol.27, pp.63-90.

STEUER, R. E. (1986). Multiple Criteria Optimization: Theory, Computation, and Applications, John Wiley \& Sons, Inc., New York.

WIERZBICKI, A. P. (1977). "Basic properties of scalarizing functionals for multiobjective optimisation", Mathematische Operationsforschung und Statistik, Optimization, Vol.8, pp.55-60.

WIERZBICKI, A. (1986). "On the Completeness and Constructiveness of Parametric Characterizations to Vector Optimization Problems”. OR Spektrum, 8, 73-87. 


\section{Appendix}

Table 1. Decision Variables.

\begin{tabular}{|c|c|c|c|c|}
\hline Name & Variable & Type & Values & Description \\
\hline \multirow[t]{2}{*}{ ghwg } & Gross Wage & Continuous & {$[0, \delta)$} & * URVVI5 HDOQ + RXUO \\
\hline & Education level: & & & $\begin{array}{c}\text { Highest education level completed } \\
\text { (reference group: first level of secondary education } \\
\text { or lower) }\end{array}$ \\
\hline edhigher & Higher education & Binary & 0 or 1 & Higher education \\
\hline edsec & Secondary education & Binary & 0 or 1 & Secondary ( $2^{\text {nd }}$ level) education completed \\
\hline netfipc & Family income & Continuous & {$[0, \delta)$} & Net Equivalent family income $\left(10^{3} \square \quad 1 / 4 \square \square\right.$ \\
\hline \multirow[t]{2}{*}{ age } & Age & Continuous & $\begin{array}{l}{[25,} \\
64]\end{array}$ & Age (years) \\
\hline & Job seniority: & & & $\begin{array}{c}\text { Seniority in the company (reference group: } 0-2 \\
\text { years) }\end{array}$ \\
\hline jobten34 & Seniority 3-4 & Binary & 0 or 1 & Seniority in the company (3-4 years) \\
\hline jobten 59 & Seniority 5-9 & Binary & 0 or 1 & Seniority in the company (5-9 years) \\
\hline jobten 1014 & Seniority $10-14$ & Binary & 0 or 1 & Seniority in the company (10-14 years) \\
\hline jobten 15 & Seniority $15+$ & Binary & 0 or 1 & Seniority in the company (15- years) \\
\hline more $40 \mathrm{~h}$ & Working hours: & Binary & 0 or 1 & Working more than 40 hours per week \\
\hline \multirow[t]{2}{*}{ permcont } & Permanent contract & Binary & 0 or 1 & $\begin{array}{l}\text { Type of contract signed: permanent } \\
\text { (reference group: non permanent; i.e. fixed term, } \\
\text { etc.) }\end{array}$ \\
\hline & Occupational status: & & & $\begin{array}{c}\text { Job status (reference group: non } \\
\text { supervisory/intermediate) }\end{array}$ \\
\hline supervisory & Supervisory & Binary & 0 or 1 & Supervisory status \\
\hline intermediate & Intermediate & Binary & 0 or 1 & Intermediate status \\
\hline married & Married & Binary & 0 or 1 & Civil State \\
\hline child6 & Children $<6$ & Binary & 0 or 1 & $\begin{array}{c}\text { Having children younger than } 6 \text { (ref. group: older } \\
\text { than 5) }\end{array}$ \\
\hline \multirow[t]{2}{*}{ unemdur } & Unemployment duration & Integer & $\begin{array}{l}{[0,} \\
288]\end{array}$ & Worker's unemployment duration (months) \\
\hline & Worker's Health: & & & $\begin{array}{l}\text { General health status (reference group: bad or very } \\
\text { bad) }\end{array}$ \\
\hline goodhealth & Good health & Binary & 0 or 1 & Health status (Good) \\
\hline fairhealth & Fair health & Binary & 0 or 1 & Health status (Fair) \\
\hline \multirow[t]{2}{*}{ regunem } & $\begin{array}{l}\text { Regional unemployment } \\
\text { rate }\end{array}$ & Continuous & $\begin{array}{c}{[0,} \\
100]\end{array}$ & Regional unemployment rate \\
\hline & Industry in current job: & & & $\begin{array}{c}\text { Main activity in current job (ref. group: } \\
\text { Manufacturing) }\end{array}$ \\
\hline ind 1 & Mining and quarrying & Binary & 0 or 1 & Industry (Mining and quarrying) \\
\hline ind 3 & Utilities and construction & Binary & 0 or 1 & Industry (Utilities and construction) \\
\hline ind 4 & Sales hotel & Binary & 0 or 1 & Industry (Sales, hotels and restaurants) \\
\hline ind5 & Transport & Binary & 0 or 1 & Industry (Transport) \\
\hline ind6 & Finance property & Binary & 0 or 1 & Industry (Finance property) \\
\hline \multirow[t]{2}{*}{ Ind 7} & Other industry & Binary & 0 or 1 & Industry (Other industry) \\
\hline & Firm size: & & & $\begin{array}{c}\text { Number of employees in current job(ref. group: less } \\
\text { than 5) }\end{array}$ \\
\hline$f_{S} 519$ & Firm size 5-19 & Binary & 0 or 1 & Firm size (5-19 workers) \\
\hline$f_{s} 2099$ & Firm size 20-99 & Binary & 0 or 1 & Firm size (20-99 workers) \\
\hline$f_{s} 100499$ & Firm size $100-499$ & Binary & 0 or 1 & Firm size (100-499 workers) \\
\hline$f_{S} 500$ & Firm size $500+$ & Binary & 0 or 1 & Firm size $(>=500$ workers $)$ \\
\hline
\end{tabular}

